\title{
The Reasons Behind the Absence of a Comprehensive Shariah Governance Framework of Islamic Banks in Bangladesh
}

Submitted 14/10/19, 1st revision 11/11/19, $2^{\text {nd }}$ revision 21/12/19, accepted 24/01/2020

\author{
Md. Kausar Alam ${ }^{\mathrm{a}}$, Suhaimi Ab. Rahman ${ }^{\mathrm{b}}$, Oli Ahad Thakur ${ }^{\mathrm{c}}$, \\ Md Abdul Bashir ${ }^{\mathrm{d}}$, and Sharif Hosen ${ }^{\mathrm{e}}$
}

\begin{abstract}
:
Purpose: The main objective of the study is to examine the reasons behind the absence of a comprehensive Shariah Governance Framework (SGF) of Islamic banks in Bangladesh.

Design/Methodology/Approach: The study has covered 17 respondents through semistructured interviews from the Islamic banks and the Central Bank of Bangladesh with a combination of Shariah supervisory board members, Shariah department executives, Central Bank executives, and banking experts.

Findings: Based on findings, this study outlines that the knowledge gap of management, unqualified Shariah supervisory boards members, executives in Central Bank and Islamic banks, and intention of the regulators, policymakers, Shariah experts, government executives, Islamic bankers, Board of directors, stakeholders and civil societies are responsible for the absence of a comprehensive $S G F$.

Practical Implications: The study has significantly contributed to the national regulators, government, and the Central Bank of Bangladesh on the subject for developing a comprehensive Shariah Governance Framework.

Originality/Value: The study highlights the reasons for the absence of a comprehensive Shariah Governance Framework which was unexplored for more than 30 years.
\end{abstract}

Keywords: Shariah Governance Framework, Islamic banks, Bangladesh.

JEL Classification: G18, G21, G28, G38.

Article Type: Research study.

\footnotetext{
$a^{*}$ Corresponding author, PhD, Faculty of Economics and Management, Universiti Putra Malaysia, Email: kausarflorence@gmail.com

${ }^{b}$ Associate Professor, Department of Management and Marketing, Faculty of Economics and Management, Universiti Putra Malaysia,Email: suhaimiabrahman@upm.edu.my

${ }^{c}$ PhD Candidate, at Putra Business School, Universiti Putra Malaysia, Email: oahad0502@gmail.com

${ }^{d}$ PhD Candidate at Faculty of Economics and Management, Universiti Putra Malaysia, Email:bashirupm@yahoo.com

${ }^{e}$ PhD Student, Faculty of Educational Studies, Universiti Putra Malaysia, Email:

sharifupm@gmail.com
} 


\section{Introduction}

The global Shariah Governance (SG) practices of Islamic Financial Institutions (IFIs) vary due to countries' legal rules and regulations to monitor the overall functions of Islamic banks and finance (Hassan et al., 2011). The governance structure is the written form of guidelines and practices by which a Board of Directors (BOD) ensures accountability, fairness, and transparency with the stakeholders (customers, investors, shareholders, management, employees, society and government) concerned with the institution. The government and regulators deliver the guidelines for controlling the institutions and safeguard the interest of the numerous stakeholders. Accordingly, Ginena and Hamid (2015) stated that SG is a complete system that outlines how IFIs follow the Shariah principles in conducting their business functions. Islamic Financial Service Board (IFSB) (2009) has demonstrated SG systems as "a set of structural procedures where IFIs assure the Shariah compliance throughout its operational activities". SG is the backbone of the IFIs because it outlines a comprehensive procedure for ensuring the Shariah rules to accomplish the business functions. Without the SG it is impossible to assure a proper Islamic financing system. Thus, Minhas (2012) outlined that a comprehensive SG structure is grounded on four pillars i.e., Shariah Supervisory Board (SSB), management and supervision, Shariah compliance and review, and lastly, transparency and disclosure.

However, Bangladesh has started its Islamic banking journey through the inauguration of the Islamic Bank Bangladesh Limited in 1983 (Hassan et al., 2017) with combined efforts of the government and general people. Currently, Bangladesh has 8 complete Islamic banks, 19 Islamic banking branches and 35 Islamic banking windows from the conventional banks (Bangladesh Bank, 2019). Though the Central Bank promulgated a guideline in 2009 still Bangladesh has an absence of a welldefined full-fledged regulatory, supervisory specific and structured governance framework to govern, supervise, monitor and regulate the Islamic banking activities (Ullah, 2014; Ahmad et al., 2014; Perves, 2015; Alam et al., 2019). Due to the absence of a separate law and a comprehensive SGF, Islamic banks have developed their SG mechanisms that are flexible in their practice (Hassan et al., 2017).

They also highlighted that Islamic banks presumed the desire to transfer the responsibilities of themselves to the BOD and take advantage of the Central Bank Islamic banking guideline. Due to the absence of a comprehensive SGF the developed model and its practices are not homogeneous. Every Islamic bank has a different organizational structure and the SSB position is not the same and well organized (Alam et al., 2019; Perves, 2015). However, there are several studies focused on the SG issues, legal and regulatory perspective, problems and prospects of SG, influence of BOD and management of SG guidelines, Shariah compliance and disclosure and the procedures of a central Shariah regulatory authority in Bangladesh (Alam et al., 2020a, 2020b; 2019; Hassan et al., 2017; Perves, 2015; Ullah, 2014; Ahmad et al., 2014). But these studies did not focus on exploring the 
reasons behind the absence of a comprehensive SGF for the Islamic banks in Bangladesh. Still, there is a question about the diverse practices as the Shariah principles if they are the same for all Islamic banks and are working in a similar banking environment. Thus, the study aims to investigate the reasons for the absence of a comprehensive SGF for the Islamic banks in Bangladesh as it started its journey in 1983.

By applying semi-structured interviews, the study found that Bangladesh has a lack of experts in the Central Bank, government, Islamic banks, SSBs members and management; thus, the guideline does not show the complete version. The intention of all concerned bodies is also responsible for the absence of a comprehensive SGF. Besides, there is a negative viewpoint about Islamic banking amongst the executives of the central bank and the government. The socio-political structure, situations, banking environment, political will and political commitment of the government are also responsible for the absence of a comprehensive SGF. Finally, Bangladesh has a deficiency in the overall efforts of arrangements amongst the Islamic banks, the Central Bank, and the government; as a result, the country has an absence of a comprehensive SGF.

Compared with other researches, this study has several contributions to the area of Islamic banking and SG literature in the context of Bangladesh to the practitioners, regulators, and policymakers. First, this study illustrates the reasons behind the absence of a comprehensive SGF of Islamic banks in Bangladesh which was unexplored form its inaugurations until now. Second, this study highlights that all of the concerned authorities of the Islamic banks in Bangladesh need to sit together to develop a comprehensive SGF with a combination of Centralized Shariah Supervisory Board (CSSB) for their proper and effective functions. Third, the Islamic banks, SSBs members, BOD of all Islamic banks, Central Bank and other regulatory bodies should sit together to promulgate a comprehensive guideline to develop a comprehensive SGF for the Islamic banking industry. Fourth, this research broadens the existing literature of Islamic banking and its SG practices concerning Bangladesh which will be helpful for the practitioners and policymakers to solve these problems and develop a unique SG guideline for its smooth functioning. In conclusion, it is suggested to develop a comprehensive SGF for enhancing better system and quality compliance of Shariah.

\section{Literature Review}

SG is the process of ensuring Shariah compliance by following the Islamic principles in the overall functions of Islamic banks and financial institutions. For protecting the unique image of this industry, Islamic banks require to institute extra units namely, SSB, Shariah executives, Shariah secretariat, Shariah audit review and research units to ensure the compliance of Shariah in their overall business functions and transactions. The presence of SSB in the SGF differentiates itself from the conventional corporate governance systems. All of these parties have the obligation 
to ensure the proper quality of Shariah compliance. For instance, BOD is responsible for the overall Shariah issues, managerial responsibilities and application of the suggestions of the SSB to protect and accomplish the demand of concerned stakeholders (BNM, 2010; 2013, AAOIFI, 2010; IFSB, 2006). Management is liable for providing the reports of Shariah compliance to the BOD (BNM, 2010; 2013; IFSB, 2006). SSB members are employed by the BOD for monitoring the overall Shariah issues in the business functions, providing their Shariah views in any problems and contemporary issues and issuing an annual Shariah report on the overall functions (Zaidi, 2008). Therefore, the efficient organizational procedure might enhance the credibility and confidence level of numerous stakeholders concerning with this industry (Greuning and Iqbal, 2008; Chapra and Ahmed, 2002).

As a banking regulator, the Central Bank outlines the rules and regulations for conventional and Islamic banks. Therefore, the Central Bank has issued the criteria for accomplishing the Islamic banking functions as per the Shariah law and the respective bank has to ensure all mechanisms for conforming Shariah compliance (Bangladesh Bank, 2009). The SGF requires that the SSB should be independent in accomplishing their functions and be formed with knowledgeable and qualified personnel in Shariah and banking to complete its duties efficiently. All the Islamic banks in Bangladesh have a separate Shariah department and Shariah executive officers who assist the SSB, monitor the overall shariah issues and report to them for their Shariah opinions and resolutions (Abdullah and Rahman, 2017). Along with the SSB, Shariah officers and their roles are significant in SG systems. The Shariah executives work as a mediator in accomplishing the SSB functions. They undertake the Shariah review and Shariah audit functions and findings submitted to the SSB for their concern and authorization which indicates that they have essential roles in the SG of Islamic banks. Besides, SSB gives their opinions on the ex-post Shariah compliance functions based on the Shariah executives report (BNM, 2010; IFSB, 2009; Pasaman, 2017; Suryanto et al., 2017; Permana, 2017; Hussain et al., 2018).

Still, the central bank did not set up any Shariah department or division for monitoring the Islamic banks. Besides, the Central Shariah Board for Islamic Banks of Bangladesh (CSBIB) started its operations in 2002 as a private organization for developing a unique SG practice in Bangladesh and performing its roles without an authorized body. Along with CSBIB, all Islamic banks have their separate SSB comprising with the prominent Shariah scholars having different names i.e., Shariah Board, Shariah Committee, and Shariah Supervisory Committee. All of the Islamic banks have formed their particular SSB and only the four Islamic banks have positioned in their organizational structure (Alam et al., 2019). Similarly, Islamic banking branches and windows also have the SSBs with renowned Shariah professionals. The SSB overlooks the overall banking activities in relation to day to day activities and performs the Shariah audit and Shariah compliance review as well as outlines their views from the Shariah viewpoints on overall functions which are printed in their yearly report and sent to the Bangladesh Bank (Abdullah and Rahman, 2017). Usually, the SSB evaluates the performance, and audit inspections 
to calculate the employees' performance and to confirm the principles of Shariah (Alamgir, 2016). Islamic banks accomplish internal Shariah reviews on current and accomplished activities in ensuring the Shariah compliance, which is mostly associated with the SSB's direction, monitoring and guiding (Rahman, 2014). In support of the activities of SSB, every Islamic bank has a separate Shariah department or Shariah Inspection and Compliance Division, which assist them in making, maintaining and presenting the documents. The officers of this section conduct the Shariah audit and the partial Shariah research activities are also performed by few Shariah department officers (Abdullah and Rahman, 2017). Therefore, the practices of the overall SG are not similar due to the absence of central guidelines from the regulatory authorities.

\section{Methodology}

To accomplish the research objective, the researchers investigated the answer to "What are the reasons for not being a comprehensive SGF?" Qualitative research has applied to explore the answers to this question. It comprises "an array of interpretive techniques which seek to describe, decode, translate, and otherwise come to terms with the meaning, not the frequency, of certain more or less naturally occurring phenomena in the social world" (Cooper and Schindler, 2011, 162). Selecting Bangladesh as case research, this research aimed to explore the actual reasons behind the absence of a comprehensive SGF in its long journey. Therefore, the interview questions were related to the regulators, SSB members, field experts and Shariah department executives of the Islamic banks regarding the SG where there is no chance of influence by the researcher towards them.

The semi-structured interview is selected by the researchers to extend more data connected to the study and to have a wider understanding of the practical aspect of the subject matter. Semi-structured interview denotes to the interview whereby "the interviewer poses a few predetermined questions but has considerable flexibility concerning follow-up questions" (Dane, 1990). This interview is selected because of its flexibility which permits the investigators to explore more thoroughly the views of respondents which may result in more and wide-ranging details of the entire assembly of answers (Dane, 1990). In addition, this technique provides the opportunity for the respondents to outline their ideas according to their knowledge and practical experiences (Saunders et al., 2007). In difference with other sorts, the semi-structured interview method is capable of expressing the more in-depth perceptive evidence based on the prepared questions of the phenomenon (Berg and Lune, 2007). This technique is vital to clarify and understand the events, designs, and procedures of behavior and able to deliver a more rigorous image of respondents' position (Bryman and Bell, 2003).

A face-to-face interview technique has been applied to collect data as it may comfort the process of achieving a clear understanding of the research topic. When an interview is taken face-to-face, it assists to stimulate the depth replies from the 
participants. This procedure helps the respondents to understand the questions more clearly (Sekaran and Bougie, 2010). A face-to-face interview protects the individuality of the respondents in outlining their views which is a vastly valued quality in the data collection process (Kvale, 1996; Gillham, 2000). However, the respondents are directly related with the policymaking, and functioning of the SGF in the Islamic banks, as well as they, have vast knowledge, familiarity, and practical experience concerning the Islamic banking activities and its SG. The research has taken interviews from the 17 respondents by using face-to-face semi-structured interview questions who are directly related to the Central Bank, Islamic banks, SSB, Shariah department and SG functioning. The respondents have given symbolic identities for protecting their confidentiality which are 'RA' (Regulatory Aspects) from the Central Bank, 'SP' (Shariah Practitioners) from the Islamic banks and lastly ' $E$ ' (Experts) who are related with the industry and research in this field.

The NVivo has been intended for analyzing huge textual data in qualitative research, as it permits more in-depth analysis and delivers more advanced tools to envisage data (Patton, 2002; Gibbs, 2002). NVivo software was used in the technique of making code, categories and themes (Strauss, 1987; Joffe and Yardley, 2004) as it allows the researcher green data management and analysis tool rather than the paper and pencil technique. At first, the researcher makes open code to identify the fruitful outcomes from the gathered data. The findings of the analysis are discussing below.

\section{Findings and Discussion}

The results of data analysis outline five types of categories regarding the reasons behind the absence of a comprehensive SGF. The identified categories are lack of experienced people, lack of intention of different parties, socio-cultural and business environment, government policy, and finally, lack of a standard way to perform it. Figure 1 shows the identified theme along with categories and illustrates with descriptions and justifications.

Figure 1. Theme of reasons behind the absence of a comprehensive SGF

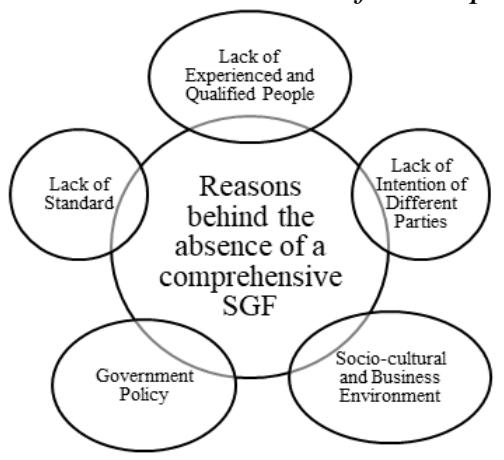

Source: Developed by the authors.

The ability of the top management regarding SG is not satisfactory, but they are 
experts and experienced people with general banking knowledge, and as a result, the guideline does not show the complete version. Sometimes, the Chief Executive Officer (CEO) of the conventional banks joins the Islamic banks as a CEO which also hinders the development of SG. Besides, Bangladesh does not have Shariah experts compared to the global standard which is also responsible for the absence of CSGF:

"Many of the conventional bankers are leaving or retiring from the conventional banks and becoming the Chief Executive Directors of the Islamic banks." [RA\#1] "We don't have the Shariah professionals." [RA\#1]

Moreover, the executives of the Islamic banks are not qualified to accomplish their functions. Along with the Shariah personnel, the executives of the central bank also lack Shariah qualified personnel. As a result, Bangladesh does not get the expected outcome in its long journey:

"They do not have a special kind of qualifications for running Islamic banks." [RA\#1] "The Shariah educated people are still not of the global standard." [RA\#1] "The central bank also has a lack of qualified people. If there are qualified people, then automatically it will impact on Islamic banks". [SP\#4]

However, the intention of different bodies such as regulators, policymakers, experts, officials, civil societies, bankers, stakeholders, and BOD is also responsible for the absence of comprehensive SGF. Therefore, they are not proactive or willful and feel inexperienced in preparing SG structure for many reasons such as official politics, negative attitudes of the colleagues, and social harassment. Every year the central bank asked Bangladesh Institute of Bank Management, a representative institution of the central bank for the problems of SG and policies of Islamic banks, but the central bank is not sincere regarding the solutions. Their intentions are limited to the theoretical aspects rather than the practicality of the implementation:

"Another thing is the intention of the government." [SP\#2] "But, they do not have the intention to progress the Islamic banking. If they really wanted then not only the Bangladesh Bank but the overall Finance Ministry or government then it would be very easy. Every year they asked for the problems, policies, statements to the research institutions Bangladesh Institute of Bank Management, a representative institution of the central bank but it is defined theoretically rather than practically implemented. [SP\#6] Most of the people, especially the high officials and even the policymakers, are very shy and not very courageous to implement Shariah in the financial institutions which are supposed to be run on the basis of Shariah. [E\#2]

Islamic banks are also not interested in SGF but rather concentrate on their business purpose and performance. As a result, they are not giving any pressure to the government, policymakers, central bank, stakeholders, academicians, researchers, civil societies and Shariah scholars to approve the SGF. They are independent to prepare their guidelines, so the guidelines are prepared according to their likings and as they wish. Indeed, they are getting the privileges from their self-developed guidelines: 
"So it did not come from the government side. I also think that the people or the influential person in the Islamic banking sector did not raise any meaningful pressure or demand from their side to the government to issue a Shariah governance system for the Islamic banks”. [SP\#2] The individual banks, they are interested in business perceptions, they should pursue government, central bank and they should pursue other stakeholders, other regulators to get their guideline or regulations and the researchers or academicians, scholars they also put their suggestions and advice, even the civil society put their suggestions as approval as given by government, central bank. [E\#5]

The foreign representatives of BOD members in IBBL do not give any pressure to the government and the central bank as well because they do not have any obligation to formulate a comprehensive SGF to comply global SG standard:

"So, the civil society also mobilizes the opinion because you (central bank) have given the license and you (central bank) will give the regulations too." [E\#5] "The stakeholders, even though the IBBL stakeholders who have the foreign representatives in the BOD they don't feel very comfortable with the global standards of the governance." [RA\#1]

In addition, there is a lack of the overall efforts of combinations amongst the Islamic banks, the central bank, and the government, and as a result, Bangladesh has an absence of a comprehensive SGF:

"It's not the issue of the bank itself, it's not the issue of the central bank, and it's a collective issue of government and the central bank." [RA\#1]

However, there are negative thinking and viewpoints against the Islamic banks and the executives from the administration section of the central bank and the government. To them, the effort is bogus and "doing the same thing in a different manner" [E\#2]. As a result, they are not motivated to do works on Islamic banking issues. Therefore, there is an allergy or negativity on their mindsets regarding the Islamic banks and SG. The officers or executives of the central bank, policymakers, and bureaucrats who have the intention to work for the Islamic banks and SG also face the problems in terms of their promotion, jobs, and goodwill. The sociopolitical structure and situations are also responsible for the absence of a comprehensive SGF:

"I will get my promotion, and if I do this, maybe the person this, my boss who doesn't like it, he's allergic to Islam or Shariah those who think that is all bogus. [E\#2] Moreover, the current social structure and political situations also responsible for this. [SP\#2]

The current conventional baking and business environment are the additional reasons for the absence of comprehensive SGF:

"We are doing Islamic banking in such an environment that where real banking business environment the conventional bank is there, an Islamic bank is there." [E\#1] 
In addition, Shariah people of Bangladesh also have a lack of knowledge compared to the global SG standard:

"If you need to run an Islamic bank, you have to have global knowledge, global standard". [RA\#1]

However, respondents (E\#3, 4, 5; SP\#8) state that it is 'national policy matter' and the government has included, amended and modified many Shariah related issues in the conventional banking act and system. Therefore, it is the ultimate responsibility of the government to promulgate the proper SG guidelines for the Islamic banks but the government also has limitations. Additionally, the central bank also has the obligation to issue sound and robust instructions as they have published the banking license. Besides, if the central bank provides new guidelines, then Islamic banks and SSB will face problems as well as it will impact on their independence in the decisions making process:

"You know, is it must be related to the government policy." [E\#4] "It is the primary responsibility of the government to give the framework or guideline." [E\#5] "So, it is again secondary responsibility of the central bank to review, proper guidance they are giving the license as per Shariah." [E\#5] "In this regard, we had a meeting a few months ago with the presence of one deputy governor he has explained this issue. In this case, the government also has limitations and bindings". [SP\#8]

Respondents (SP\#2, 5) narrate that the political will and political commitment of the government are also responsible for the absence of comprehensive SGF. The government is not prioritizing and patronizing the Islamic banks directly as the main banking stream is conventional banks. There is also a different mentality among government officials concerning Islamic banking. The bankers are also responsible for the absence of a comprehensive guideline for the Islamic banks in Bangladesh:

"Because it needs the political will of the government. The main reason is that the government is not directly assisting the Islamic banks in its proper development. One is works on behalf of Islamic banks and another group is not like this". [SP\#2]

In conclusion, Islamic banks and bankers are not ready for the expected guidelines. If the central bank issue new guidelines, they have to follow the guidelines which will impact their Shariah decision, implementations, and accountability:

"Our bankers are also not prepared, not committed." [SP\#5] "If there have the CSSB it is also better. If does not have, then in another side, it also good. In this case, you can make your own policy then you will become under bindings". [SP\#8]

From the above discussion, SG is considered as regulatory issues; thus it is the responsibility of the government to outline a comprehensive guideline for the Islamic banks. Additionally, the Islamic banks, BOD, and management are not interested in CSGF since they can be benefited from their self-developed governance guidelines. Overall, there is an absence of intention of all concerned bodies for developing a CSGF and SSB members lack the knowledge. 


\section{Conclusions and Recommendations}

The study aimed to find out the reasons behind the absence of a comprehensive SGF for the Islamic banks in Bangladesh. Form the findings of the analysis, this study finds that Bangladesh has a lack of experts in all levels of Islamic banking and the Central Bank concerning the SG guidelines. There is a lack of intentions about the homogeneous SGF among the policymakers, regulators, government and Islamic bankers. As the Islamic banks are privileged in the self-developed practices; thus, they also have less interest in the unique guideline. Besides, the social, political structure, government intention, political will and banking system of the country also responsible for the absence of a unique SGF in the country. Finally, it is suggested to develop a comprehensive SGF for proper monitoring of the overall functions and Shariah issues of the Islamic banks which will be better for the banking industry and country. The government, regulators and Central Bank should prioritize the Islamic banking sector for continuous development and progress of the country's economy. Islamic banks, bankers and BOD should develop their mental make up to follow the unique guideline if it provides by the central bank or regulators.

However, this research also has some beneficial contributions to the regulators, policymakers and Islamic banks as well as the existing literature of the Islamic banking sector of Bangladesh. Firstly, this is the first study that highlighted the reasons for the absence of a comprehensive SGF for the Islamic banks in Bangladesh. Secondly, the study explored the numerous reasons and gaps amongst the concerned authorities for the absence of a comprehensive SGF. Thirdly, the Islamic banks, BOD and management should motivate the Central Bank to develop a unique SG guideline for themselves and need to grow their mental make up to follow those guidelines rather than self-developed manual. Fourthly, the government should focus on Islamic banking issues for its proper monitoring and Shariah functioning. Finally, the regulators should prioritize Islamic banks like conventional banks as they are contributing to the economy of the country.

Therefore, the study is limited to the Islamic banks of Bangladesh rather than including other Islamic banking practicing countries such as Malaysia, Pakistan, and Indonesia as well as Gulf countries, for example, Saudi Arabia, Qatar and Iran. Besides, this research does not cover the non-bank financial institutions and Islamic insurance companies of Bangladesh. However, future researchers can also examine the other sectors why Islamic insurance does not have an inclusive SGF for its functioning. It is recommended to justify the other countries like Saudi Arabia and Qatar for their absence of broad SG guidelines. Furthermore, the researchers can justify the findings by applying quantitative methodology concerning Bangladesh and other jurisdictions. 


\section{References:}

AAOIFI. 2010. Accounting, Auditing and Governance standards for Islamic financial institution. Manama, Bahrain.

Abdullah, M.F., Rahman, A. 2017. Shari'ah Governance of Islamic Banks in Bangladesh: Issues and Challenges. Journal of Islamic Economics, Banking and Finance, 13(3), 82-94.

Ahmad, A.U.F., Rashid, M., Shahed, A.K.M. 2014. Perception of Bankers and Customers towards Deposit and Investment Mechanisms of Islamic and Conventional Banking: Empirical Evidence from Bangladesh. Journal of Islamic Business and Management, 4(2), 91-114.

Alam, M.K., Rahman, S.A., Mustafa, H., Shah, S.M., Hossain, M.S. 2019. Shariah Governance Framework of Islamic Banks in Bangladesh: Practices, Problems and Recommendations. Asian Economic and Financial Review, 9(1), 118-132.

Alam, M.K., Tabash, M.I., Thakur, O.A., Sahabuddin, M., Hosen, S., Hassan, M.F. 2020a. A central Shariah regulatory authority for the Islamic banks in Bangladesh:

Legalization or formation. Journal of Asian Finance, Economics and Business, 7(1), 91-100.

Alam, M.K., Miah, M.S, Siddiquii, N., Hossain, M.I. 2020b. The Influences of board of directors and management in shariah governance guidelines of the Islamic banks in Bangladesh. Journal of Islamic Accounting and Business Research. (Forthcoming). DOI: 10.1108/JIABR-08-2019-0155

Alamgir, M. 2016. An Analysis of Islamic Banking Activities in Bangladesh: Issues and Challenges. Thoughts on Economics, 25(03-04), 29-58.

Bangladesh Bank. 2009. Guideline for conducting Islamic banking. Dhaka, Bangladesh.

Bangladesh Bank. 2019. Bangladesh Bank Quarterly report on 'Developments of Islamic Banking in Bangladesh' January-March, 2019. Bangladesh Bank, Dhaka, 2016.

BNM. 2010. Shariah Governance Framework for Islamic Financial Institutions (BNM/RH/GL 012-3). Kuala Lumpur: Bank Negara Malaysia.

BNM. 2013. Islamic Financial Service Act 2013. Kuala Lumpur, Bank Negara Malaysia.

Berg, B.L., Lune, H. 2007. Qualitative research methods for the social sciences. Pearson Education Inc, Boston.

Bryman, A., Bell, E. 2003. Business research methods. Oxford University Press, USA.

Chapra, M.U., Ahmed, H. 2002. Corporate governance in Islamic financial institutions. Occasional Paper No. 6, Islamic Research and Training Institute/Islamic Development Bank, Jeddah.

Cooper, R.D., Schindler, S.P. 2011. Business Research Methods. Eleventh ed. Singapore: McGraw-Hill/Irwin.

Dane, F.C. 1990. Research Methods, Brooks/Cole Publishing, Belmont, California.

Gibbs, G. 2002. Qualitative data analysis: explorations with NVivo. Open University.

Ginena, K., Hamid, A. 2015. Foundations of Shari'ah governance of Islamic banks. UK: John Wiley \& Sons.

Gillham, B. 2000. Developing a questionnaire. London, Continuum.

Greuning, H.V., Iqbal, Z. 2008. Risk Analysis for Islamic Banks. Washington, World Bank.

Hassan, M.K., Ullah, M.H., Khanam, R. 2017. Shariah Governance Practices in Bangladesh. Chapter in Shariah Governance Systems and Practices in a Globalized World, Edited by Nazim Ali.

Hassan, R., Abdullah, N.I., Hassan, A., Ibrahim, U., Sawari, M.F.M., Abd. Aziz, A., Triyanta, A. 2011. A Comparative Analysis of Shariah Governance in Islamic 
Banking Institutions across Jurisdictions. International Shariah Research Academy for Islamic Finance. Kuala Lumpur.

Hussain, H.I., Shamsudin, M.F., Salehuddin. S. and Jabarullah, N.H. 2018. Debt Maturity and Shariah Compliance: Evidence from Malaysian Panel Data. European Research Studies Journal, 21(1), 176-186.

IFSB. 2006. Guiding principles on corporate governance for institutions offering only Islamic financial services (excluding Islamic insurance (takaful) institutions and Islamic mutual funds). Kuala Lumpur: International Financial Service Board.

IFSB. 2009. Guiding Principles on Shari'ah Governance Systems for Institutions Offering Islamic Financial Services. Kuala Lumpur: Islamic Financial Services Board.

Joffe, H., Yardley, L. 2004. Content and thematic analysis. Research methods for clinical and health psychology. California, Sage, 56-68.

Kvale, S. 1996. Interviews: an introduction to qualitative research interviewing. Thousand Oaks, Sage.

Minhas, I. 2012. Shari'ah governance model (SGM) and its four basic Pillars. Islamic Finance News Malaysia Published by Red Money Publication. Available at: https://ssrn.com/abstract=2153106.

Patton, M.Q. 2002. Qualitative research and evaluation methods. 3rd ed. California, SAGE.

Permana, D. 2017. Toward the Best Model of Strategy Implementation in Indonesian Islamic Banking from the Lens of Strategic Clarity. European Research Studies Journal, 20(4B), 3-15.

Perves, M.M. 2015. Legal and Regulatory Framework in Islamic Banking System: Bangladesh Perspective. European Journal of Business and Management, 7(21), 179-188.

Pasaman, S. 2017. The Effect of Capital Adequacy Ratio, Net Interest Margin and NonPerforming Loans on Bank Profitability: The Case of Indonesia. International Journal of Economics \& Business Administration, 5(3), 70-80.

Rahman, J.M. 2014. Cost-Benefit Analysis of Implementing Shari'ah Auditing as a Separate Discipline in Bangladeshi Islamic Banks, 1-18. Retrieved from http://ssrn.com/abstract=2538590 or http://dx.doi.org/10.2139/ssrn. 2538590 .

Saunders, M., Lewis, P., Thornhill, A. 2007. Research Methods for Business Students. Prentice Hall, Hemel Hempstead.

Sekaran, U., Bougie, R. 2010. Research Methods for Business: A skill building approach. Wiley.

Strauss, A.L. 1987. Qualitative analysis for social scientists. Cambridge University Press.

Suryanto, T., Thalassinos, E.J., Thalassinos, I.E. 2017. Board Characteristics, Audit Committee and Audit Quality: The Case of Indonesia. International Journal of Economics \& Business Administration, 5(3), 47-57.

Ullah, H. 2014. Shari'ah compliance in Islamic banking - An empirical study on selected Islamic banks in Bangladesh. International Journal of Islamic and Middle Eastern Finance and Management, 7(2), 182-199.

Zaidi, J.A. 2008. Shari'a harmonization, regulation and supervision. Paper presented at the AAOIFI-World Bank Annual Conference on Islamic Banking and Finance, Manama, Bahrain. 